\title{
Potential of Multispectral Satellite Data for Superficial Iron Oxide Detection in Sulaimaniyah, Iraqi Kurdistan Region
}

\author{
Ayad M. Fadhil Al-Quraishi1 ${ }^{*}$, Banaz M. Mustafa ${ }^{2}$, P. Gopinathan ${ }^{3}$, Y. Divya ${ }^{4}$ \\ ${ }^{1}$ Department of Surveying and Geomatics Engineering, Tishk International University, Erbil 44001, Kurdistan Region, \\ Iraq.ayad.alquraishi@gmail.com \\ ${ }^{2}$ Deptartment of Soil and Water Sci., College of Agriculture, Salahaddin University, Erbil 44003, Kurdistan Region, \\ Iraq. \\ ${ }^{3}$ CSIR - Central Institute of Mining and Fuel Research, Ministry of Science and Technology, Govt. of India, Dhanbad, \\ Jharkhand, 828108, India. srigopi555@ gmail.com \\ ${ }^{4}$ Department of Earth \& Environment, Florida International University, Miami, FL, 33199, USA. \\ divyayuvaraj86@gmail.com
}

*Correspondence: Ayad Al-Quraishi (ayad.alquraishi@gmail.com; ayad.alquraishi@tiu.edu.iq)

\begin{abstract}
This study primarily investigates the total (Fe) iron presence in Sulaimaniyah Governorate, the Iraqi Kurdistan Region (IKR), which has an abundance of iron mines. Spatial quantification and frequent monitoring of mineral existence in the soil are essential in the mining regions. To achieve this goal, a remote sensing technique was utilized to predict soil minerals, particularly iron existence in the study area using a multispectral satellite image, Landsat-7 Enhanced Thematic Mapper Plus (ETM+). A robust methodology was perceived and developed from image processing to estimate and map iron oxides rich soils, and soil's spectral indices were obtained after algorithms applied in processing on the bands of Landsat image. Soil samples were collected and analyzed in the laboratory to determine the chemical, physical, and mineralogical characteristics of soils. Correlation coefficients were carried out between soil properties and spectral band values retrieved from image analysis to examine the band potentials of Landsat. The statistical results showed that there was a significant relationship between the $3^{\text {rd }}$ band of the ETM+ image and each of the total iron $\left(R^{2}=0.643\right)$, the free iron oxide $\left(R^{2}=0.659\right)$, and sand particles $\left(R^{2}=0.561\right)$. The predicted soil mineral maps were generated for the study area to visualize the study site's soil characterization and total iron spread. This study results could help primarily identify the spatial distribution of some soil properties in Sulaimaniyah, Iraq.
\end{abstract}

Keywords: Iron Oxide, Multispectral Satellite Data, Landsat ETM+, Sulaimaniyah, Iraqi Kurdistan Region

Received: Nov. $4^{\text {th }} 2020$ /Accepted: Dec. $28^{\text {th }} 2020 /$ Online: Jan. $2^{\text {nd }} 2021$

\section{Introduction}

Numerous factors govern the mineral resources of soil on Earth, and one of the main factors is iron content (Fe) (Stucki et al. 1988). Iron oxides influence the range of $\mathrm{pH}$ values, temperature, oxidation-reduction capacity, and water content in the soil environment. It is evidenced that Fe oxide plays a vital role in soil quality (Rossel et al., 2010). Iron (Fe) is an essential element in the Earth's crust and is the fourth most abundant 
element in the lithosphere after oxygen, silicate, and aluminum. It composed 5\% of the Earth's crust, while its average content in soils is estimated at 3.8\% (Lindsay, 1979). Previous studies reported that the study area is rich in iron minerals; even the small proportion in specific soil has iron content. In Mosul governorate, Iraq, the total Fe concentration in five soil samples ranged from 3.45 to $4.89 \%$ (Al-Aathami, 1981). The total Fe concentration ranged between 4.5 to $6.6 \%$ in four Erbil calcareous soils (Al-Malak, 1986). Meanwhile, the total Fe content of the soil from Abu-Gharib is $3.42 \%$ (Al-Azawy, 1988). The total Fe concentration ranged between 1.39 to $6.45 \%$ in some alluvial fan soils (Mohamed, 1988). Al-Jadoa (1990) reported that Fe's total concentration is ranged between 1.7 and $3.85 \%$ in the soil samples taken from sedimentary plain, undulatory, and Jazeera region. Examining a group of soils at Aski Kalak soil showed that the total Fe concentration ranged from 0.54 to $2.13 \%$ (Al-Obaidi et al., 1994). The Hussainiyat ironstone deposit, where the mines are in, contains mainly goethite and haematite (Al-Bassam \& Tamar-Agha, 1998). Sposito (1989) reported Fe oxides' intense pigments to give many soils their red, yellow, orange, or brown color even at low concentrations (fewer percent). Prior studies depicted that the study area region has a good source of iron minerals in soils, and it needed any non-destructive technique for quantifying the iron oxide.

Identifying and retrieving the number of iron minerals from the soil is a challenging task, and there is an advanced technology required to achieve it. After investigating the previous works involved in soil minerals studies, remote sensing/geoinformatics technology was used for its potential and rapid mapping. The visible near-infrared (NIR) region of spectroscopy is used in many studies for analyzing soil properties. The color of soil indirectly represents few Soil properties such as organic matter, carbonates, and iron oxides (Baumgardner et al., 1985). Hence, the spectroscopy's visible range can be used to get detailed soil color data (Rossel et al.2010). Iron ions can easily substitute into octahedral sites and less into tetrahedral sites, thus retained in soils. This can majorly affect spectroscopy absorption features (Hunt, 1980, Weismiller et al., 1985). Remote sensing datasets and techniques were effectively used in several environmental applications in several countries (Fadhil, 2011, 2013, Wu et al., 2019, Gaznayee \& Al-Quraishi, 2019, Alqasemi et al., 2021, Alqasemi et al. 2020, Kumar et al., 2019, Al-Quraishi et al., 2021, Wu et al., 2018, Yao et al., 2011). The surface mineralogical features can be effectively mapping by remote sensing technology, especially Iron oxide, which has significant influences on the soil's spectral reflectance characteristics (Ciampalini et al., 2012). Al-Quraishi et al. (2019) has utilized a Landsat ETM+ image, soil chemical and physical properties laboratory analyses, and statistical analysis to find the statistical correlations among the physicochemical and spectral properties of soil in some sites of the IKR.

The soil index map is different from that of the ferrous minerals in such a way that the iron oxide includes all the materials showing red color on the ground. In other words, it includes iron ores, red soils, and laterites (Gopinathan et al., 2020). The mineral-specific color results from their interaction with visible light and depends on both the crystal structure and particle size but several studies using the NIR region for getting effective results in the analysis of iron oxide. Utilizing satellite images has potentially given more significant correlations to the field data in iron oxide analysis, specifically Landsat images (Ducart et al., 2016, Madani, 2008, White et al., 1997). The freely available Landsat data used in this study experiment with the Iron oxide existence in the IKR soils in northern Iraq. This region possibly exploits local iron oars and represents iron mines in the Bawari Valley (Moorey, 1994).

Along with multispectral data, GIS tools enhanced this study by mapping soil properties. GIS manipulated the soil properties as attributes and helped visualize the study site's soil classification (Mather \& Koch, 2011, Divya et al., 2020). The current study's main objectives are: 1) To examine the potential of geoinformatics techniques to depict, map, and assess the iron-rich soils in the study region using the Landsat -7 ETM+ image, 2) To process the ETM+ image and retrieve band details and other spectral indices for soil analysis, 3) To generate a 
statistical regression model between the spectral indices retrieved from satellite image and soil lab data and test the predicted models' significance.

\section{The Study Area}

The study area for this research (Figure 1) is a part of the Sulaimaniyah Governorate in the IKR (North of Iraq), which covers an area of $(9,829.0) \mathrm{Km}^{2}$. The IKR majorly has a combination of flatlands, hills, valleys, and mountains. The study area's main features are located between Qandil, Sara, Peramagron, Sagrma, Swren, Mlakawa, and Goezha mountains, which reach in height up to 3,600 m above sea level (a.s.l.) with snow coverage at high altitudes. A smoother morphology occurs in the central part. However, the high area is characterized by an anticline or syncline system (Boccaletti and Dainelli, 1982), which gives rise to relief with a general orientation NE-SE. The study area's climate shows typical Mediterranean environments' typical characteristics (Buondonno et al., 1987, Leone et al., 1989).

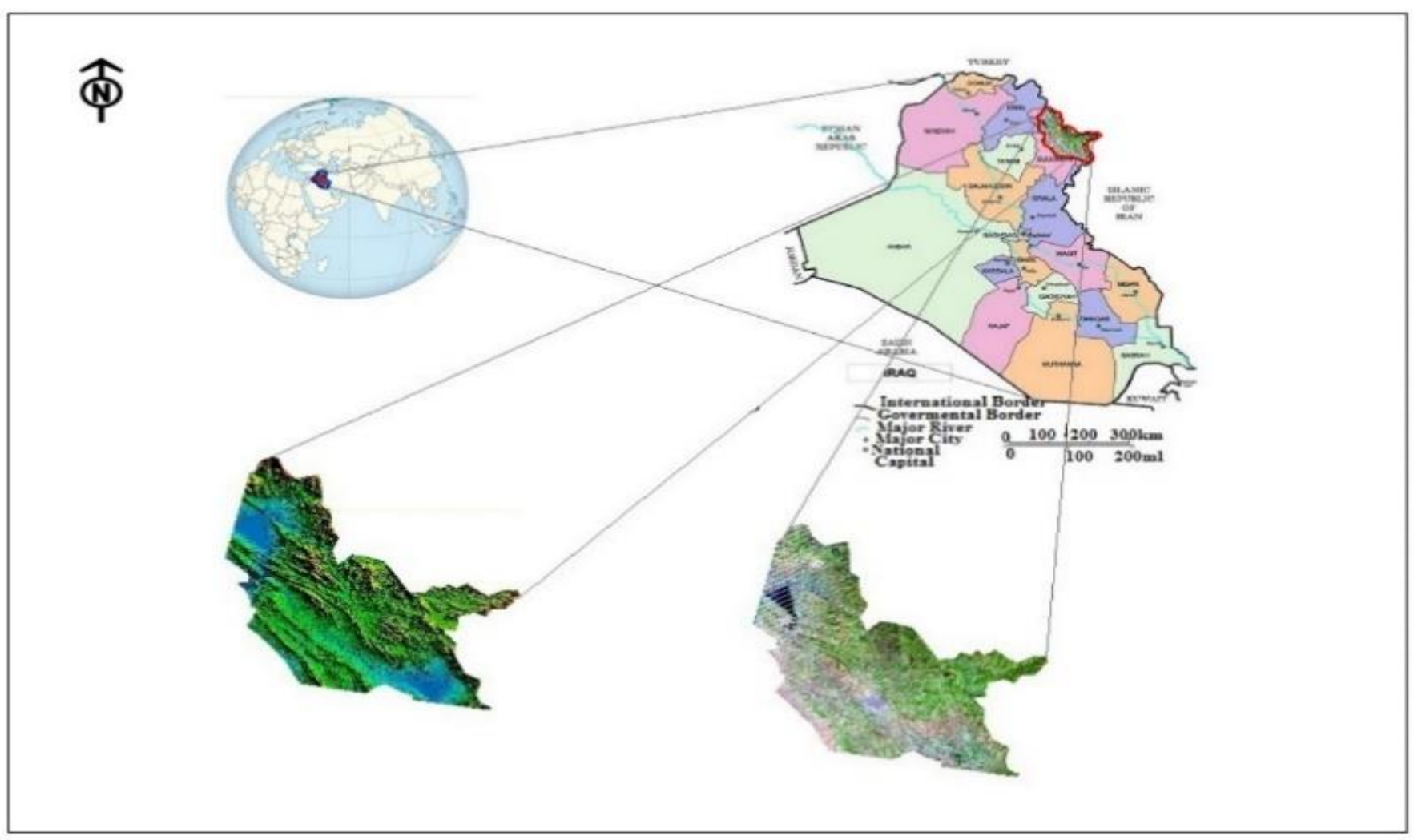

Figure 1: Location map of the study area with its Landsat7 ETM+ RGB 741color composite and the DEM.

The Sulaimaniyah Governorate comprises twelve districts, which are: Sulaimaniyah, Halabja, Derbandikhan, Kalar, Chamchamal, Chwarta, Penjuin, Dukan, Qaladza, Qaradagh, Shahrazoor, and Rania. Sulaimaniyah city is located $400 \mathrm{~km}$ North-East of Baghdad, the capital city of Iraq. The study site was divided into three zones with 39 sampling locations for further soil chemical and physical laboratory analyses, as shown in Figure 2.

\section{Materials and Methods}

\subsection{Collection and Preparation of Soil Samples}

The current study methodology is divided majorly into three parts (Field, Laboratory, and Office) that are described in the flowchart in Fig 3. Thirty-nine soil samples were collected from different Sulaimaniyah 
Governorate locations from July 2012 to June 2013 (Figure 2). The samples were taken from the soil surface layer (0-15) cm depth. After passing the soil samples through a $2 \mathrm{~mm}$ sieve series (ASTM). The sieved soil samples are taken to determine the physical, chemical, and spectral characteristics properties. Similarly, the soil samples passed through (0.425) mm sieve for determining the Percent Linear Shrinkage (PLS) test. The study areas had different soil colors indicated by using Munsell color parameters (Hue, Value, and Chroma) observable in the field. For each soil sample (dry and moist) the color was among the followings: (Brown, Dark Brown, Very Dark Brown, Strong Brown, Dark Grayish Brown, Very Dark Grayish Brown, Yellowish Brown, Light Yellowish Brown, Dark Yellowish Brown, Pole Brown, Dark Reddish Brown, Olive Brown, Light Olive Brown, and Pink). The sample collection was completed one by one zone, as shown in Figure 2.

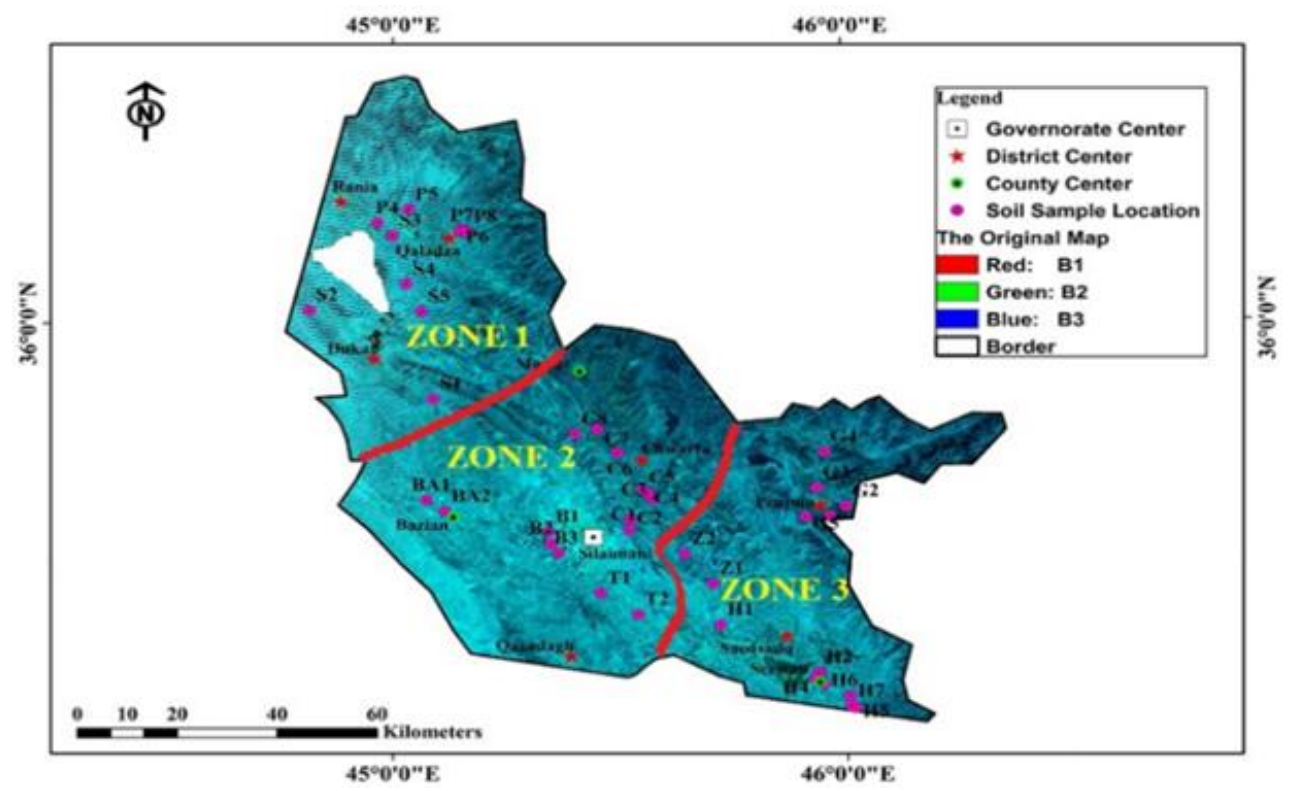

Figure 2: The three zones of the study area

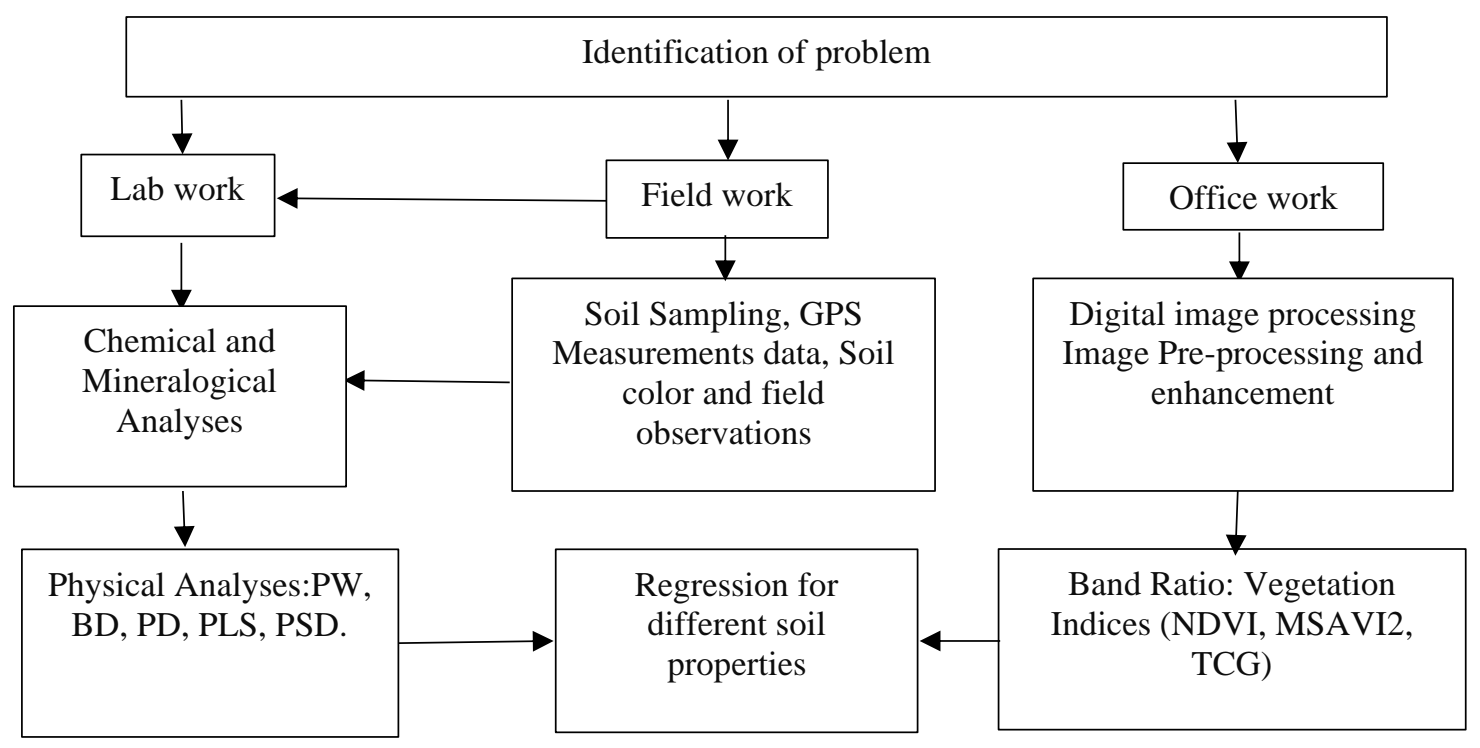

Figure 3. Methodology flowchart 


\subsection{Soil Laboratory Analyses}

The following physical analyses are done to obtain the soil physical and chemical properties for the study's soil samples: Particle size distribution was performed by the pipette method (Van Reeuwijk, 1995). Bulk density is determined using the clod method covering the samples with paraffin wax, as described by Black, 1965. Specific gravity (using pycnometer) particle density and liquid limit tests were determined as per ASTM, (1986) guidelines. The percent of linear shrinkage was measured according to the British Standards Institution method, 1975. Soil moisture content was measured by the gravimetric method, as mentioned in Gardner (1986).

The chemical analyses were conducted on soil extract 1:2 (Soil: $\left.\mathrm{H}_{2} \mathrm{O}\right)$ as explained in the following sentences. The electrical conductivity was measured using an EC- meter. The soil's pHwas measured using a pH-meter model described in prior works (Van Reeuwijk, 1995). Sodium and potassium ions were determined by the flame photometer method model. Organic matter (OM) was measured by the Walkley and Black method in Nelson \& Sommers (1982). Calcium carbonate was determined by the acid neutralization method, according to Rowell (1996). Cation exchange capacity was determined to utilize $(1 \mathrm{~N}) \mathrm{NaOAC}$ solution $(\mathrm{pH}=8.2)$, and Available phosphorus was measured by using the Olsen procedure in Ryan et al. (2001). Total nitrogen was estimated by the Kjeldahl digestion-distillation method in Bremner \& Mulvaney (1982). The soluble cations and anions were determined according to the procedures outlined in Page et al. (1982). The total iron was digested by the Kjeldahl method as reported in Bremner \& Mulvaney (1982) and then measured by an Atomic absorption spectrometer (AA 700) with a wavelength $(248.3 \mathrm{~nm}$ ). Iron oxide removal from soils and clays by a dithionite- citrate system buffered with sodium bicarbonate and measured by an Atomic absorption spectrometer (Mehra \& Jackson, 1953). Table 1 shows the different soil properties of the study area according to its sampling points. The soil properties indicated that there is a wide range of iron oxide existence. The $\mathrm{pH}$, $\mathrm{EC}$, and OM values of soils are shown to encouraging crop growth conditions.

\subsection{Landsat Dataset and Image Processing}

A Landsat 7 ETM+ (path 168/row 35) acquired on (1 ${ }^{\text {st }}$ Sep 2012) was downloaded for the study region with a 30m spatial resolution. The Landsat ETM+ imagery was radiometrically corrected to eliminate the cls-off error using a histogram matching technique in ENVI 5.3. The seven bands pixel values were retrieved for each sampling site after the image processing. The freely available data and most successful geosciences studies promoting Landsat satellite data are necessary for remote sensing analysis. Prior studies evidenced that Red and NIR regions were best suited for iron mapping (Dematte et al., 2006). SWIR and NIR regions eased to identify soil classification. Landsat ETM+ image was geometrically corrected in datum WGS84 and projection UTM zone N38 using first order (linear) of a polynomial function and Nearest Neighbor rectification re-sampling, which was chosen to preserve the radiometry and spectral information in the imagery. The Landsat image was radiometric calibrated and converted into reflectance at sensor values using the ENVI software.

\section{Results and Discussion}

\subsection{Spatial Analysis}

In a raster model, the spatial analysis would refer to patterns and covariations in pixel values of one or more data layers. Topics include network analysis, point pattern analysis, trend analysis, spatial interpolation, sampling, and exploratory data analysis (Mather and Koch, 2011). Modeling requires a good understanding of the system being modeled, and it incorporates several steps (Barnsley, 2007). After the necessary transformations, we investigated possible relationships between soil chemical and physical properties and the Landsat ETM+ image-based DN values of the soil samples's location by correlation (Pearson) analysis and then modeling the significant linear regression relationships. This analysis considered only the strong and significant (positive or negative correlations) relationships for developing robust models (Dogan \& Kilic, 2013). 
Table 1: The chemical and physical properties of the study area soil samples

\begin{tabular}{|c|c|c|c|c|c|c|c|c|c|}
\hline $\begin{array}{c}\text { Sample } \\
\text { ID }\end{array}$ & Zone & $\begin{array}{c}\text { Sample } \\
\text { Locations }\end{array}$ & EC & PH & OM & $\begin{array}{c}\text { PSD } \\
\text { sand } \\
\text { gm/kg }\end{array}$ & Total Fe & $\begin{array}{c}\text { Free } \\
\text { Iron } \\
\text { Oxide }\end{array}$ & $\begin{array}{l}\text { Free Fe / } \\
\text { Total Fe }\end{array}$ \\
\hline $\mathrm{H} 1$ & Zone 3 & KaniPanka & 0.25 & 7.26 & 15.3 & 32.5 & 4.63 & 2.97 & 0.64 \\
\hline $\mathrm{H} 2$ & Zone 3 & Serwan1 & 0.22 & 7.1 & 11.9 & 33.0 & 3.10 & 1.9 & 0.61 \\
\hline $\mathrm{H} 3$ & Zone 3 & Serwan2 & 0.20 & 7.2 & 21.3 & 81.2 & 2.30 & 2.12 & 0.92 \\
\hline $\mathrm{H} 4$ & Zone 3 & Kelaspe & 0.20 & 7.25 & 21.3 & 59.1 & 4.93 & 3.62 & 0.73 \\
\hline H5 & Zone 3 & QlejiAnab & 0.25 & 7.19 & 23.2 & 89.8 & 3.10 & 0.34 & 0.1 \\
\hline H6 & Zone 3 & Darashesh & 0.20 & 7.76 & 22.0 & 147.4 & 1.89 & 0.32 & 0.16 \\
\hline $\mathrm{H} 7$ & Zone 3 & Anab & 0.21 & 7.95 & 19.9 & 71.5 & 2.06 & 0.22 & 0.1 \\
\hline $\mathrm{P} 4$ & Zone 1 & Rania & 0.20 & 7.83 & 10.9 & 69.0 & 5.10 & 1.32 & 0.25 \\
\hline P5 & Zone 1 & Bastasen & 0.20 & 7.88 & 10.6 & 70.3 & 6.40 & 1.63 & 0.25 \\
\hline P6 & Zone 1 & Qaladza & 0.25 & 7.84 & 15.3 & 164.4 & 7.28 & 1.84 & 0.25 \\
\hline $\mathrm{P} 7$ & Zone 1 & QutkeHasar & 0.25 & 7.83 & 15.3 & 180.7 & 7.91 & 1.45 & 0.18 \\
\hline P8 & Zone 1 & Dere & 0.35 & 7.74 & 19.9 & 332.0 & 49.40 & 16.65 & 0.33 \\
\hline $\mathrm{C} 1$ & Zone 2 & Sharisten & 0.19 & 7.27 & 32.0 & 112.3 & 5.14 & 2.02 & 0.39 \\
\hline $\mathrm{C} 2$ & Zone 2 & Bnawela & 0.20 & 7.20 & 27.9 & 133.6 & 15.57 & 3.22 & 0.2 \\
\hline $\mathrm{C} 3$ & Zone 2 & Kani Sard1 & 0.19 & 7.19 & 15.3 & 55.0 & 16.81 & 16.6 & 0.98 \\
\hline $\mathrm{C} 4$ & Zone 2 & Kani Sard2 & 0.30 & 7.20 & 8.6 & 153.8 & 25.44 & 17.26 & 0.67 \\
\hline $\mathrm{C} 5$ & Zone 2 & Kani Sard3 & 0.20 & 7.27 & 3.3 & 400.7 & 28.18 & 18 & 0.63 \\
\hline C6 & Zone 2 & Wazha & 0.20 & 7.17 & 15.3 & 194.0 & 31.09 & 15.45 & 0.49 \\
\hline $\mathrm{C} 7$ & Zone 2 & Kunamase & 0.22 & 7.25 & 4.5 & 88.8 & 21.64 & 16.26 & 0.75 \\
\hline $\mathrm{C} 8$ & Zone 2 & Kareza & 0.21 & 7.20 & 21.3 & 33.5 & 22.77 & 15.57 & 0.68 \\
\hline $\mathrm{B} 1$ & Zone 2 & ZankoeAmreke & 0.21 & 7.17 & 15.9 & 41.5 & 9.14 & 2.01 & 0.21 \\
\hline $\mathrm{B} 2$ & Zone 2 & Twezhenawa & 0.32 & 7.89 & 15.9 & 51.6 & 5.35 & 2.03 & 0.37 \\
\hline B3 & Zone 2 & Bakrajo & 0.25 & 7.92 & 19.9 & 87.0 & 8.34 & 1.65 & 0.19 \\
\hline S1 & Zone 1 & Surdash & 0.20 & 7.28 & 18.6 & 80.7 & 3.67 & 1.49 & 0.4 \\
\hline S2 & Zone 1 & KaniMazu & 0.20 & 7.37 & 23.3 & 69.5 & 3.47 & 1.74 & 0.5 \\
\hline S3 & Zone 1 & BardaKoz & 0.21 & 7.37 & 11.9 & 47.0 & 6.80 & 2.09 & 0.3 \\
\hline $\mathrm{S} 4$ & Zone 1 & Sewkan & 0.22 & 7.27 & 13.3 & 59.4 & 5.56 & 1.63 & 0.29 \\
\hline S5 & Zone 1 & Kunamar & 0.29 & 7.32 & 11.9 & 65.0 & 2.66 & 2.27 & 0.85 \\
\hline BA1 & Zone 2 & Baziyan1 & 0.25 & 7.01 & 17.3 & 99.9 & 3.40 & 1.11 & 0.32 \\
\hline BA2 & Zone 2 & Baziyan2 & 0.40 & 7.97 & 17.3 & 73.3 & 2.81 & 2.17 & 0.77 \\
\hline $\mathrm{T} 1$ & Zone 2 & Zrguez & 0.29 & 7.05 & 11.9 & 92.5 & 3.34 & 1.62 & 0.48 \\
\hline $\mathrm{T} 2$ & Zone 2 & Tanjaro & 0.30 & 7.92 & 20.6 & 232.8 & 13.74 & 1.48 & 0.1 \\
\hline $\mathrm{Z} 1$ & Zone 3 & Barzinja & 0.20 & 7.00 & 11.9 & 18.5 & 3.45 & 1.13 & 0.32 \\
\hline $\mathrm{Z} 2$ & Zone 3 & Gelara & 0.20 & 7.19 & 21.3 & 23.0 & 4.17 & 3.17 & 0.76 \\
\hline G1 & Zone 3 & Blekyan & 0.16 & 7.19 & 37.2 & 457 & 21.62 & 15.75 & 0.72 \\
\hline $\mathrm{G} 2$ & Zone 3 & Bashmax & 0.27 & 7.20 & 65.2 & 272 & 19.12 & 12.15 & 0.63 \\
\hline G3 & Zone 3 & Kelw & 0.18 & 7.17 & 18.6 & 489 & 24.42 & 17.84 & 0.73 \\
\hline G4 & Zone 3 & Garmk & 0.21 & 7.37 & 15.3 & 66.0 & 17.91 & 2.05 & 0.11 \\
\hline G5 & Zone 3 & Penjuin & 0.17 & 7.46 & 9.9 & 152.0 & 19.23 & 2.34 & 0.12 \\
\hline
\end{tabular}


Modeling the relationships between Landsat-7 ETM+ bands DN values with soil surface variables enabled to map of these soil variables on a spatially explicit basis. The soil variables selected for linear regression analysis show the most substantial positive or negative correlations with the ETM+ bands' DN values. Dogan \& Kilic (2013) indicated that the modeling is the relationship between Landsat-7 ETM+ bands DN values and some soil surface variables enabled us to map these soil variables on a spatially explicit basis.

The produced soil properties models were converted to grid map layers by utilizing the correlated Landsat-7 ETM+ bands and the ERDAS ERMapper package. The outcomes of simple linear regression were summarized in models. The model summary reported the correlation coefficient ( $r$ ) between the dependent variable's observed and predicted values. The regression model explained the coefficient of determination $\left(\mathrm{R}^{2}\right)$ in the dependent variable. The produced [Free Fe, Total Fe, and Sand] maps from the developed models had two main advantages. First, they established an updated spatial database of the focused soil variables. Second, they presented a chance for monitoring processes that could reveal temporal changes. The model was then used to predict the full extent of the original map. Moreover, the regression statistics showed that the developed models were robust.

\subsection{Statistical Correlations}

Pearson correlation coefficients of the raw data were calculated with their significance values. The correlation was simply the covariance measured for standardized variables. To standardize a variable mean value was subtracted from all measurements, and the result was divided by the standard deviation (Mather \& Koch 2011). The regression models were demonstrated for all the tested soil properties with the entire spectral bands of Landsat, but here the best-suited variables are only presented for further discussion. The model summary that the regression model explained the correlation coefficient ( $\mathrm{r}$ ) between the observed and predicted values of the dependent variable and the coefficient of determination $\left(\mathrm{R}^{2}\right)$ in the dependent variable. Large values (close to 1) of (r) and $\mathrm{R}^{2}$ indicated a strong relationship and well-fitted model, respectively, using the SPSS package. Experimental models are essential tools for relating field-measured variables remotely sensed data. The regression analysis has been a prevalent empirical method of linking these two types of data to supply continuous environmental variables estimates (Cohen, et al., 2003). Then defined soil chemical and physical properties and ETM+ bands' DN values as dependent (y) and independent (x) variables. Prediction models mapping for regression showed 15 strong (positive and negative correlations) relationships for developing robust models. Consequently, 15 sets of linear regression were employed to develop eight distinct models shown in table 2. Each model is classified into five classes that were very low, low, moderate, high, and very high. Means, minimums, maximums, medians, skewness, and coefficient of variations (CVs) of selected soil properties were calculated using statistical software. Data normality was tested using the Anderson-Darling (A-D) test using statistical software at a significance level of 5\%. Pearson correlation coefficients were calculated for all soil properties and data (Khan et al., 2012).

Numerous soil properties governed the spectral bands. For example, Bowers \& Hanks (1965) indicated that with increasing particle size from 2200 to $2650 \mathrm{~nm}$, at least an additional $14.6 \%$ of the direct solar radiant energy was found to be absorbed. From table 1, it can be inferred that the particle size of sand influenced the $3^{\text {rd }}$ ETM+ band region with reasonable accuracy $\left(\mathrm{R}^{2}=0.561\right)$. West et al. (2004) supported this view by explicating particle size's influence on soil spectral reflectance revealed rapid in $485 \mathrm{~nm}$. Theoretically, a decrease in the particle size would increase reflectance. This increment is caused by heavier light scattering and lower extinction of light, passing through the particles (NASA, 1987). Fine textures generally show greater reflectance than coarse textures (Horvath et al.,1984). Besides particle size, soil spectral reflectance is also affected by other particle characteristics, such as sphericity and micro-roughness at the surface of textural elements (Mulders, 1987). This study found that the $3^{\text {rd }}$ band of the ETM+ image is the best band suited for sand particle modeling. 
The total iron and free iron oxide governed well in the $3^{\text {rd }}$ ETM+ band region as well. It has shown a strong correlation with the highest correlation values $\left(\mathrm{R}^{2}=0.659\right)$ and $\left(\mathrm{R}^{2}=0.643\right)$, respectively. Dematte et al. (2006) found many of the absorption features in soil reflectance spectra are due to the presence of iron in some form. The main absorption bands were centered at 450 and $850 \mathrm{~nm}$ and were attributed to interactions between EMR and iron oxide content in the soil. One of the earliest studies by Obukhov \& Orlov (1964) researched that decreases in reflectance with increasing iron oxide percentage in the visible region of the spectrum (500-640 $\mathrm{nm})$. The results revealed a negative significant between the $6^{\text {th }}$ band of ETM+ and OM by $\left(\mathrm{R}^{2}=0.207\right)$, which means the temperature decreased when the OM content increased.

Table 2: Summary of linear regressions equations for different models utilizing the ETM+ image bands

\begin{tabular}{|c|c|c|}
\hline Model & $\mathbf{R}^{2}$ & Regression Equation \\
\hline Free Iron Oxide \& Band 3 & 0.659 & Free $\mathrm{Fe}_{2} \mathrm{O}_{3}=45.137+(-180.290)(\mathrm{B} 3)$ \\
\hline Total Fe \& Band 3 & 0.643 & Total $\mathrm{Fe}=62.897+(-235.390)(\mathrm{B} 3)$ \\
\hline Sand $\&$ Band 3 & 0.561 & Sand $=822.751+(-3309.011)(B 3)$ \\
\hline Total N \& Band 1 & 0.277 & $\mathrm{~N}=3.676+(-12.802)(\mathrm{B} 1)$ \\
\hline $\mathrm{Na}_{2} \mathrm{O} \&$ Band 7 & 0.262 & $\mathrm{Na}_{2} \mathrm{O}=0.676+(-2.207)(\mathrm{B} 7)$ \\
\hline O.M\& Band 6 & 0.207 & $\mathrm{O} . \mathrm{M}=607.727+(-1.864)(\mathrm{B} 6)$ \\
\hline $\mathrm{K} \&$ Band 1 & 0.205 & $\mathrm{~K}=0.853+(-4.976)(\mathrm{B} 1)$ \\
\hline Mg \& Band 2 & 0.204 & $\mathrm{Mg}=1.315+(-4.455)(\mathrm{B} 2)$ \\
\hline
\end{tabular}

In the regression analyses, soil variables were defined as dependent (y) variables, while the Landsat-7 ETM+ bands DN variables were considered independent $(\mathrm{x})$ variables. The obtained models were then explained using equations for the form $\mathrm{y}=\mathrm{a}+\mathrm{bx}$ formula (Dogan \& Kilic, 2013).

The validation test was carried out to check the regression models to represent the estimated soil properties' spatial existence for total iron and free iron oxide compared to laboratory analyses. The results showed that the predicted and measured results define nature's reality. The regression-based predicted maps are shown in Figs. 4, 5, 6. Similarly, other locations such as (C4, C6, C7, C8, G1, and G3) that recorded a high value of total Fe are indicated by orange color in figure 4. On the other side, regression model maps (Figs. 4,5) were the very high class pointed by the blue color of total Fe and free iron oxide, at the east of the study area was very high. While the iron oxide was (Fig. 4), the very high class was the brown color in most study areas. The sample validations had the same reality as the results of the laboratory analyses and spectral prediction models. Predictive performances of the fitted models are checked based on cross-validation. 


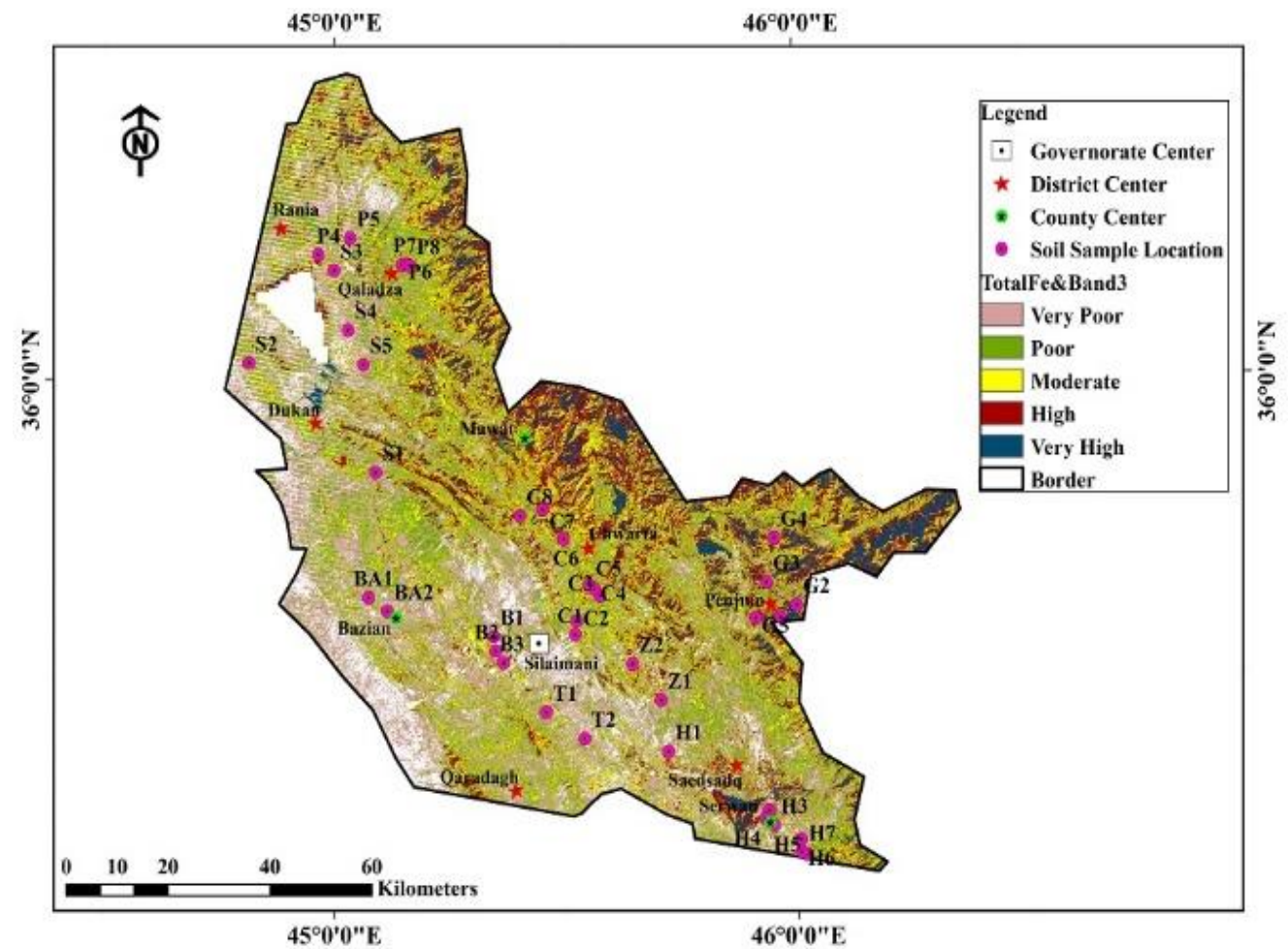

Figure 4. The regression-based classified map of the (Total Fe) using the third band of the ETM+

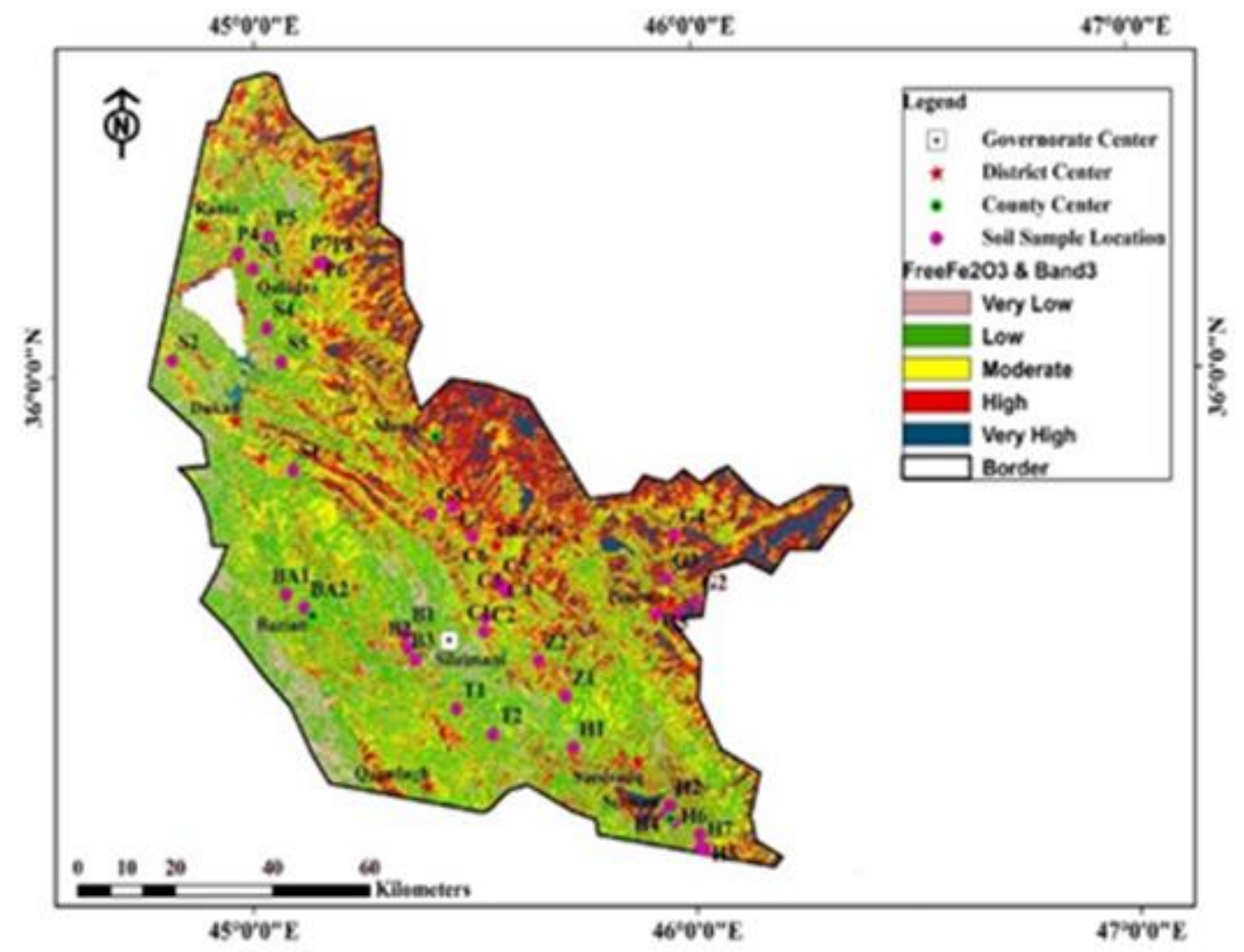

Figure 5. The regression-based classified map of (free $\mathrm{Fe}_{2} \mathrm{O}_{3}$ ) using the third band of the ETM+ 


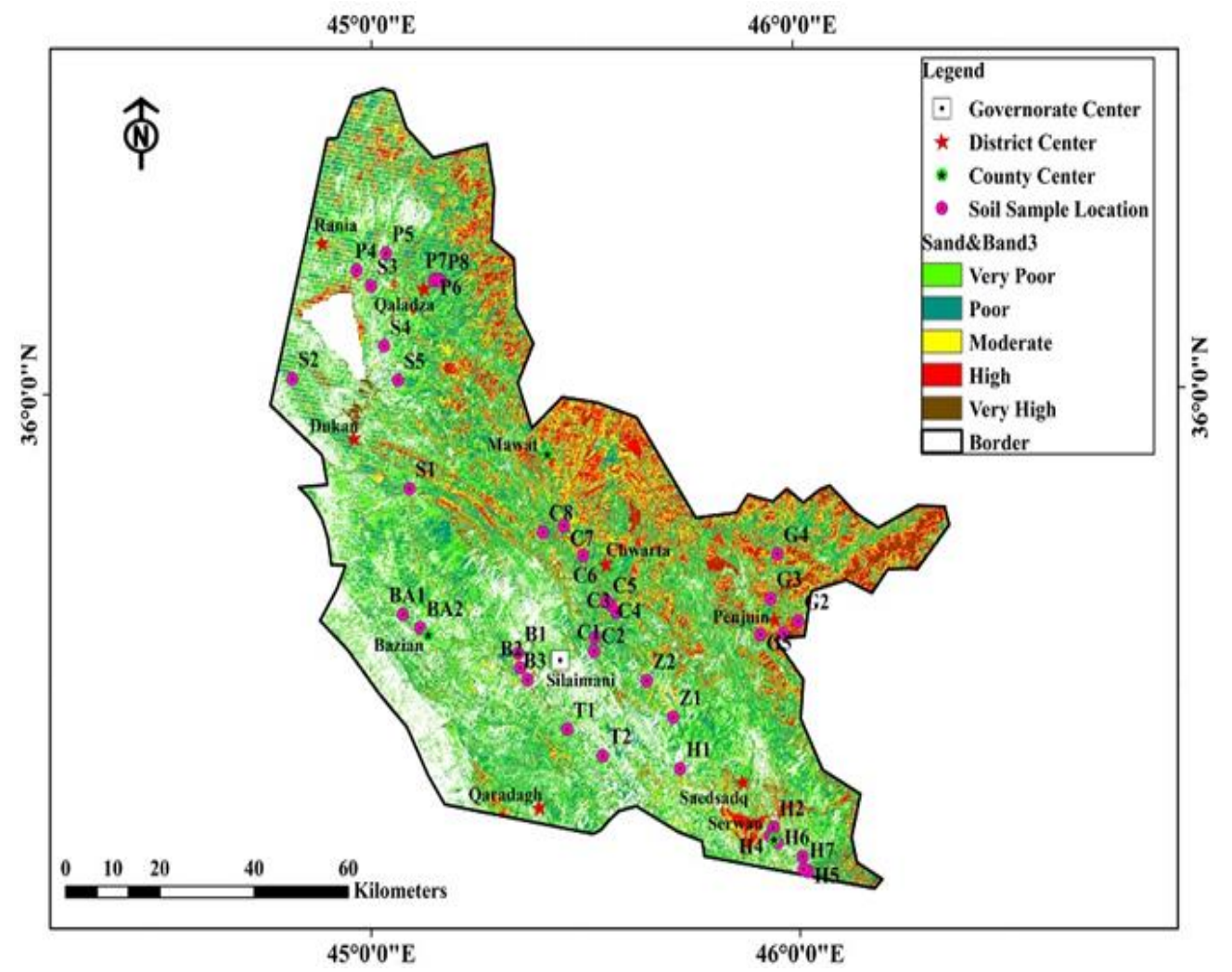

Figure 6: The regression-based classified map of sand particles using the third band of the ETM+

\section{Conclusions}

According to the results of the present study, the following conclusions were extracted:

- Modeling the specific soil minerals and spatial distribution using DN numbers of Landsat image is thinkable with reasonable accuracy.

- The Landsat-7 ETM+ image bands' statistical analyses revealed a significant negative correlation $(\mathrm{R} 2=$ $0.659)$ between the free iron and band 3 (Red). When the amount of free iron in soil increased, the reflectance decreased, similarly with the total iron $(\mathrm{R} 2=0.643)$ and band3 (Red). High iron content contributed to the lower reflectance.

- This study predicted an interesting fact about soil sand particles dominance in the third band of the Landsat 7 ETM+ image along with iron content of soils evidenced with good correlation $(\mathrm{R} 2=0.561)$. This will lead to further future soil textural analysis.

- The current study evidenced that geoinformatics techniques can be utilized for iron mineral quantification and non-destructive methods. This study results can be used at the agriculture research stations to improve the agricultural conditions in IKR.

\section{Acknowledgment}

The authors would like to thank and extend their gratitude to the United States Geological Services (USGS) for the free available Landsat satellite images.

\section{References}

Al-Aathami, Z. A. (1981). Studies of some effecting factors on iron Availability in alluvial and brown soil. M.Sc. Thesis. College of Agricultural. Mosel University. Iraq.

Al-Azawy, K. M. N. (1988). Influence of nitrogen and iron application on growth, yield and nutrient content of soil and corn plant. M.Sc. Thesis, Dept. of Soil, Coll. of Agri., Baghdad Univ., Iraq. 
Al-Bassam, K.S., \& Tamar-Agha, M.Y. (1998). Genesis of the Hussainiyat ironstone deposit, Western Desert, Iraq. Mineralium Deposita 33: 266-282.

Al-Jadoa, A. K. (1990). Iron, manganese, zinc, and copper in soil particles. Ph. D. Thesis, Dept. of Soil, College of Agric., Baghdad Univ., Iraq.

Al-Malak, S. D. (1986). Iron availability in some calcareous soils in northern Iraq. M.Sc. thesis, Dept. of Soil Science, College of Agric. Salahadin University, Erbil, Iraq.

Al-Obaidi, M. A. J., Khalil, N. F. \& Sadullah, M. (1994). Iron status in some soils of Northern Iraq. Jour. Agron. Sci. No.2.

Alqasemi, A. S. , Hereher, M. E., Al-Quraishi, A. M. F., Saibi, H., Aldahan, A. \& Abuelgasim, A. (2020). Retrieval of monthly maximum and minimum air temperature using MODIS Aqua land surface temperature data over the United Arab Emirates (UAE). Geocarto International, DOI: 10.1080/10106049.2020.1837261

Alqasemi, A. S., Hereher, M. E., Kapland, G., Al-Quraishi, A. M. F. \& Saibi, H. (2021). Impact of COVID-19 lockdown upon the air quality and surface urban heat island intensity over the United Arab Emirates. Science of The Total Environment, 767, 144330. DOI: 10.1016/j.scitotenv.2020.144330

Al-Quraishi, A. M. F., Gaznayee, H. A. A., \& Crespi, M. (2021). Drought Trend Analysis in Sulaimaniyah (Iraqi Kurdistan Region) for the Period 1998-2017 using Remote Sensing and GIS. J. of Arid Land (In Press).

Al-Quraishi, A. M. F., Sadiq, H. A., \& Messina, J. P. (2019). Characterization and Modeling Surface Soil Physicochemical Properties Using Landsat Images: A Case Study in the Iraqi Kurdistan Region. Int. Arch. Photogramm. Remote Sens. Spatial Inf. Sci., XLII-2/W16, 21-28, DOI: 10.5194/isprs-archives-XLII-2-W16-21-2019

ASTM. (1986). Standard test methods for liquid limit, plastic limit, and plasticity index of soils. ASTM International, West Conshohocken.

Barnsley, M. J. (2007). Environmental Modeling: A Practical Introduction, CRC Press, Boca Raton.

Baumgardner, M. F., Silva, L. F., Biehl, L. L., \& Stoner, E. R. (1985). Reflectance properties of soils. In: N. C. Brady Ed. Advances in Agronomy 38. Academic Press Inc. Orlando, Florida, pp.1-44

Black, C. A. (Ed.). (1965). Methods of soil analysis. Amer. Soc. of Agron. Series No. 9. Madison, Wis.

Boccaletti, M., \& Dainelli, P. (1982). RegmaticosystemNeogenico-Quaternary Mediterranean nell'area: esempio di deformazione plastic-collisionale rigid post. Memorial Society of Geology, Vol. 24.

Bremner, J. M. \& Mulvaney, C. S. (1982). Nitrogen - Total. P. 595-622. In: Page et al. (ed.) Methods of soil analysis. Part 2. chemical and microbiological properties. Agron. Monogr. 9. ASA, Madison, WI.

Buondonno, C, Leone, A. P., Ortolani, F., Pagliuca, S., \& Tedeschi, P. (1987). Marginal area 'Fortorebeneventano'. Help diattito excursion. (National Council of Research Department: Irrigation Institute).

Ciampalini, A., Garfagnoli, F., \& Antonielli, B. (2013). Remote sensing techniques using Landsat ETM+ applied to the detection of iron ore deposits in Western Africa. Arab J Geosci 6, 4529-4546. DOI: 10.1007/s12517-012-0725-0.

Cohen, W. B., \& Goward, S. N. (2004). Landsat's Role in Ecological Applications of Remote Sensing. Bioscience 54: pp.535-545.

Dematte, J. A. M., Nanni, M. R., Formaggio, A. R. \& Epiphanio, J. C. N. (2006). Spectral reflectance for the mineralogical evaluation of Brazilian low clay activity soils. Sao Paulo, Brazil.

Divya, Y., Gopinathan, P., Jayachandran, K., \& Al-Quraishi, A.M.F. (2020). Color slices analysis of land use changes due to urbanization in a city environment of Miami Area, South Florida, USA. Model. Earth Syst. Environ. https://doi.org/10.1007/s40808-020-00883-X.

Dogan, H. M., \& Kilic, O. M. (2013). Modeling and mapping some soil Surface properties of Central Kelkit Basin in Turkey by using Landsat-7 ETM+ images Turkey. Int. J. of Remote Sensing, 3(15),5623-5640.

Ducart, D. F., Silva, A. M., Labouré, C., Toledo, B. \& de Assis, L. M. (2016). Mapping iron oxides with Landsat-8/OLI and EO1/Hyperion imagery from the Serra Norte iron deposits in the Carajás Mineral Province, Brazil.Instituto de Geociências, Brazilian Journal of Geology, 46(3), São Paulo July/Sept.

Fadhil, A. M. (2011). Drought mapping using Geoinformation technology for some sites in the Iraqi Kurdistan region. Int. Journal of Digital Earth, 4(3), 239-257. doi: 10.1080/17538947.2010.489971

Fadhil, A. M. (2013). Sand dunes monitoring using remote sensing and GIS techniques for some sites in Iraq", Proc. SPIE 8762, PIAGENG 2013: Intelligent Information, Control, and Communication Technology for Agricultural Engineering, 876206 (19 March 2013); DOI: 10.1117/12.2019735

Gardner, W. H. (1986). Water content. In: Klute, A. (ed.) Methods of soil Analysis.ASA and SSSA, Madison, WI, pp. 493544.

Gaznayee, H. A., \& Al-Quraishi, A. M. F. (2019). Analysis of Agricultural Drought's Severity and Impacts in Erbil Province, the Iraqi Kurdistan Region based on Time Series NDVI and TCI Indices for 1998 through 2017. Jour of Adv Research in Dynamical \& Control Systems, 11(11),287-297. DOI: 10.5373/JARDCS/V11I11/20193198

Gopinathan, P., Parthiban, S., Magendran, T., Al-Quraishi, A. M. F., Singh, A.K., \& Singh, P.K. (2020). Mapping of ferric (Fe ${ }^{3+}$ ) and ferrous $\left(\mathrm{Fe}^{2+}\right)$ iron oxides distribution using band ratio techniques with ASTER data and geochemistry of Kanjamalai and Godumalai, Tamil Nadu, south India. Remote Sensing Applications: Society and Environment, 18,100306, DOI: 10.1016/j.rsase.2020.100306 
Horvath, E. H., Post, D. F., \& Kelsey, J. B. (1984). The relationships of Landsat digital data to the properties of Arizona Rangeland. Soil Science Society American Journal, 48,1331-1334.

Hunt, G. R. (1980). Electromagnetic radiation: The communications link inremote sensing. In: Remote Sensing in Geology (Siegal, B. S., and Gillespite, A. R. Eds.). Wiley New York, pp. 5-45

Khan, F. S., Zaman, , Q. U., Farooque, A. A. \& Saleem, S.R. (2012). Relationship of soil properties to apparent ground conductivity in wild blueberry fields .Truro, Nova Scotia, Canada

Kumar, M., Al-Quraishi, A. M. F. \& Mondal, I. (2021). Glacier changes monitoring in Bhutan High Himalaya using remote sensing technology, Environmental Engineering Research, 26(1), 190255, DOI: 10.4491/eer.2019.255

Leone, A. P., Wright, G. G. \& Corves, C. (1995). The application of satellite remote sensing for soil studies in upland areas of Southern Italy. NT. J. Remote Sensing, 16, 6, 1087-1105.

Lindsay, W. L. (1979). Chemical equilibria in soils. Wiley Inter science. New York.

Madani, A. A. (2009). Utilization of Landsat ETM+ Data for Mapping Gossans and Iron Rich Zones Exposed at Bahrah Area, Western Arabian Shield, Saudi Arabia. Earth Sci., 20(1), 35-49.

Mather, P. M. \& Koch, M. (2011). Computer Processing of Remotely-Sensed Images. University of Nottingham and Center for Remote Sensing Boston University. Fourth Edition. John Wiley and Sons Ltd, The Atrium, Southern Gate, Chichester, West Sussex, PO19 8SQ, UK.

Mehra, O. P. \& Jackson, M. L. (1955). Iron oxide removal from soils and Clays by a dithionite- citrate system buffered with sodium bicarbonate. Madison, Wisconsin.

Mohamed, I.J. (1988). The chemical behavior of zinc, copper, and other selected nutrients elements in some Iraqi arid soils. Ph. Degree Thesis State. Univ. of Ghent, Belgium

Moorey, P. R. S. (1994). Ancient Mesopotamian Materials and Industries. Oxford. http://journals.cambridge.org/abstract_S0003581500047673

Mulders, M. A. (1987). Remote sensing in soil science. Developments in soil science, vol. 15, Elsevier, Amsterdam, pp.379

NASA. (1987). Ada style guide. Version 1.1, SEL-87-002. Greenbelt. Maryland: NASA, Goddard Space Flight Center.

Nelson, D. W., \& Sommers, L.E. (1982). Total carbon, organic carbon, and organic matter. pp. 539 -580. In. Page, A. L., Miller, R., H., Keeney, DR. (eds.) Methods of soil analysis. Part 2. Chemical and microbiological properties. Agron. Monogr. 9. ASA, Madison, WI Oxford University Press, pp.277

Obukhov, A. I. \& Orlov, D. S. (1964). Spectral reflectivity of the major soil groups and possibility of using diffuse reflection in soil investigations. Soviet Soil Science (Engl. Transl) 2, 174-184.

Page et al., (ed.). (1975). Methods of soil analysis. Part 2. Chemical and microbiological properties. Agron. Monogr. 9. ASA, Madison.

Rossel, R. A., Bui, E. N., de Caritat, P. \& McKenzie, N. J. (2010). Mapping iron oxides and the color of Australian soil using visible-near-infrared reflectance spectra, J. Geophys. Res., 115, F04031, DOI:10.1029/2009JF001645.

Rowell .D. L. (1996). Soil science: Methods and applications. Longman. Group UK Limited. pp. 50 - 51.

Ryan, J., Estefan, G. \& Rashid, A. (2001). Soil and plant analysis laboratory manual. $2^{\text {nd }}$ edition, International Center for Agriculture Research in the Dry Areas (ICARDA).

Sposito, G. (1989). The Chemistry of Soils (Chaps. 8 and 9). New York

Stucki, J.W., Goodman, B.A., Schwertmann. (1988). Iron in Soils and Clay Minerals. NATO Science Series C:1988. U.Springer Netherlands. Series ISSN 1389-2185.

Van Reeuwijk. L. R. (1995). Procedures for soil analysis. International soil reference and information center, technical paper 9. pp. 3-8. $5^{\text {th }}$ edition.

Weismiller, R. A., Van Scoyoc G. E., Pazar S. E., Latz K., \& Baumgardner M.F. (1985). Use of soil spectral properties for monitoring soil erosion. In: S.A. El-Swaify Ed., Proc. Conf. Soil Erosion and Conservation, Jan.16-22, Hawaii, pp.119127

West, S. L., White, G. N., Deng, Y., Mcinnes, K. J., \& Dixon, J.B. (2004). Kaolinite, halloyside, and iron oxide influence on physical behavior of formulated soils. Soil Science Society of America Journal, 68, 1452-1460.

White, K., Walden, J., Drake, N., Eckardt, F. \& Settlell, E. (1997). Mapping the iron oxide content of dune sands, Namib Sand Sea, Namibia, using landsat thematic mapper data. Remote Sensing of Environment, 62(1):30-39

Wu, W, Muhaimeed, A.S., Al-Shafie, W.M. \& Al-Quraishi, A.M.F. (2019). Using L-band radar data for soil salinity mapping-a case study in Central Iraq, Environ. Res. Commun.1081004, DOI: 10.1088/2515-7620/ab37f0

Wu, W., Zucca, C., Muhaimeed, A.S., Al-Shafie, W.M., Al-Quraishi, A.M.F., Nangia, V., Zhu, M., \& Liu, G. (2018). Soil salinity prediction and mapping by machine learning regression in Central Mesopotamia, Iraq. Land Degradation and Development, 29(11): 4005-4014, DOI:10.1002/ldr.3148

Yao, Y., Qin, Q., Fadhil, A. M., Li, Y., Zhao, S., Liu, S., Sui, X., \& Dong, H. (2011). Evaluation of EDI derived from the exponential evapotranspiration model for monitoring China's surface drought, Environmental Earth Sciences 63(2): 425-436, DOI: $10.1007 / \mathrm{s} 12665-011-0972-5$ 